\title{
Impact of Bt sweet corn on lepidopteran pests in Midwestern Brazil
}

\author{
Altair Marcos Schneider ${ }^{1}$, Lessando Moreira Gontijo ${ }^{2 *}{ }^{(0)}$, Lilian Lucia Costa ${ }^{3}$
}

\author{
${ }^{1}$ Monsanto Brasil - Estação Experimental de Morrinhos - \\ 75650-000 - Morrinhos, GO - Brasil. \\ 2Universidade Federal de Viçosa/Centro de Ciências \\ Agrárias, Rod. LMG 818, km 06 - 35690-000 - Florestal, \\ MG - Brasil. \\ IInstituto Federal Goiano, BR-153, km 633 - 75650-000 - \\ Morrinhos, GO - Brasil. \\ *Corresponding author <lessandomg@ufv.br>
}

Edited by: Alberto Soares Corrêa

Received August 08, 2017

Accepted December 29, 2017

\begin{abstract}
While the cultivation of conventional Bt corn has been widely adopted in Brazil, the production of Bt sweet corn is still incipient. The main lepidopteran pests found attacking conventional and sweet corn in Brazil are Spodoptera frugiperda (J.E. Smith) and Helicoverpa zea (Boddie). Additionally, a new harmful Lepidoptera species has recently appeared in Brazil, Helicoverpa armigera (Hübner). Since Bt sweet corn in Brazil is as yet cultivated on a limited scale there is no scientific information available about the performance of Bt sweet corn against lepidopterans out in the field. Thus, we conducted two field experiments to evaluate the efficacy of Bt sweet corn (event MON89034), alone and in conjunction with insecticides, against major lepidopteran pests found in midwestern Brazil (in the state of Goias). Both experiments followed a completely randomized block design $(2 \times 2$ factorial) with two levels of sweet corn (Bt or conventional) crossed with two levels of insecticide (insecticide or no insecticide). The experimental treatments were replicated six times in each experiment. The results showed a slower advancing of defoliation caused by $S$. frugiperda in treatments with Bt corn. Likewise, less severe injury was observed on the corn ears (especially on the kernels) of Bt plants. The number of larvae (S. frugiperda and Helicoverpa spp.) sampled was also lower in the treatments with Bt corn. Overall, the application of insecticide did not increase the protection of Bt sweet corn and there was no significant difference in corn ear size and weight, nor in kernel yield, when comparing Bt and insecticide-sprayed plants.
\end{abstract}

Keywords: Spodoptera frugiperda, Helicoverpa, transgenic, insecticide

\section{Introduction}

Sweet corn, Zea mays L., is cultivated on over 36,000 ha in Brazil, with $90 \%$ of the production concentrated in the state of Goias. While the cultivation of conventional Bt corn has been widely adopted in Brazil (James, 2013); the cultivation of Bt sweet corn is still incipient. Examples of the main lepidopteran pests that attack conventional and sweet corn in Brazil are Spodoptera frugiperda (J.E. Smith) and Helicoverpa zea (Boddie) (Valicente, 2015). Additionally, Helicoverpa armigera (Hübner) is a new invasive pest in Brazil, which has engendered a certain apprehension amongst growers as it is a polyphagous pest capable of feeding on various crops including corn (Tay et al., 2013).

According to the sweet corn industry personnel in the state of Goias, during each growing season there will be an average of seven insecticide sprayings to manage lepidopteran pests. However, the cultivation of transgenic crops could lead to a reduction in the application of insecticide (Phipps and Park, 2002; Shelton et al., 2002; Shelton et al., 2013), and allow for integration with selective insecticides (Musser and Shelton, 2003). The benefits of this integration are a reduction in selection pressure that slows the development of resistance to Bt and synthetic insecticides, and the mitigation of insecticide non-target effects (Musser and Shelton, 2003; Romeis et al., 2006; Meissle et al., 2011). Among the main insecticides used to control lepidopterans in Bt sweet corn in the United States are lambda-cyhalothrin, methomyl, spinosad and idoxacarb (Musser and Shelton, 2003).
Among the transgenic sweet corn events available on the market are MIR 162 and MON 89034, one of the most commonly used, which has received Bt genes that encode two distinct protoxins, Cry 1A105 and Cry 2Ab2 (Drury et al., 2008), specifically aimed at controlling lepidopteran pests such as $S$. frugiperda, H. zea and Diatraea saccharalis (Fabricius) in Brazil (CTNBio, 2009). In fact, the event Mon89034 has shown to be effective against various lepidopterans in corn fields in the southern United States, including the fall armyworm Spodoptera frugiperda (Siebert et al., 2012). To date there have been no field experiments in Brazil demonstrating the effectiveness of Bt sweet corn. Furthermore, it is unknown whether or not the application of insecticide is necessary to complement the lepidopteran control provided by Bt sweet corn alone. Thus, we conducted two field experiments to examine the efficacy of Bt sweet corn (event MON89034) against lepidopterans in midwestern Brazil (in the state of Goias), alone and again when combined with insecticides. More specifically, we evaluated (i) injury caused by lepidopterans, (ii) infestation level by lepidopteran larvae, and (iii) corn yield.

\section{Materials and Methods}

This study was carried out at an experimental station in Morrinhos, in the state of Goias, Brazil (coordinates $17^{\circ} 54^{\prime} 02^{\prime \prime} \mathrm{S}, 49^{\circ} 14^{\prime} 17^{\prime \prime} \mathrm{W}$, and altitude of 841 $\mathrm{m})$. Two distinct field experiments were conducted one month apart, and were located $10 \mathrm{~m}$ apart from each other. These areas had been previously planted with millet Pennisetum glaucum (L.) which was desiccated 
with glyphosate (1440 g a.i. ha ${ }^{-1}$ ) 20 days prior to sowing the corn. The seed sowing took place on 18 Nov and 19 Dec of 2014, for experiments 1 and 2, respectively. The corn was cultivated with zero tillage. A manual seed drill sowed the seeds into the soil under the dry biomass mat formed by the desiccated millet, and allowed a 0.75 $\mathrm{m}$ distance between rows (seed density based on 58000 plants $\left.\mathrm{ha}^{-1}\right)$. Concomitantly, the soil received a dose of fertilizer (NPK; 8-30-20) of $450 \mathrm{~kg} \mathrm{ha}^{-1}$, following soil chemical analysis.

Both experiments followed a completely randomized block design $(2 \times 2$ factorial) with two levels of sweet corn (Bt or conventional) crossed with two levels of insecticide (with insecticide spray or without). In both experiments each treatment was replicated six times. Each replicate was represented by a plot containing six rows of corn with a row length of $5 \mathrm{~m}\left(22.5 \mathrm{~m}^{2} /\right.$ replicate). A border (buffer) of four additional corn rows was maintained between replicates to avoid possible cross interference. The Bt technology used was VT PRO registered by Monsanto as event MON89034, which expresses the protoxins Cry1A105 + Cry2Ab2 (Performance Series). The hybrid isoline used in all treatments was Seminis 006. Prior to each experiment the seeds of both treatments were treated with the fungicide Fludioxonil $(2.5 \mathrm{~g}$ a.i./60 000 seeds) and the insecticide Thiamethoxam $(42$ $\mathrm{g}$ a.i./60 000 seeds) to provide initial protection against diseases, sap-feeding insects, and underground insects. Additionally, weed management was carried out at the V4 stage by spraying Atrazine (2500 g a.i. ha ${ }^{-1}$ ) and Tembrione (42 g a.i. ha ${ }^{-1}$ ), subsequently complemented at stages V6 and V12 by manual removal. Management of sweet corn diseases was also carried out at stage V10 by spraying Azoxystrobin (60 g a.i. ha ${ }^{-1}$ ) and Cyproconazole (24 $\mathrm{g}$ a.i. $\left.\mathrm{ha}^{-1}\right)$ on all treatments.

The treatments with insecticide were sprayed seven times in both experiments at stages V4, V6, V8, V10, V12, R1 and R2. Some of the applications involved the combination of two active ingredients (Table 1). The number of applications is the average sprayed by the sweet corn industry in the region. The insecticides used in this region and their application rates are described in Table 1 . They were sprayed on using a $\mathrm{CO}_{2}$ backpack

Table 1 - Insecticides, application rates and the respective phenological stages when the application occurred.

\begin{tabular}{llr}
\hline Stage & \multicolumn{1}{c}{ Insecticide } & g a.i ha ${ }^{-1}$ \\
\hline V4 & Chlorantraniliprole & 25.00 \\
V6 & Lambda-Cyhalothrin & 7.50 \\
V6 & Chlorantraniliprole & 15.00 \\
V8 & Methomyl & 126.00 \\
V8 & Lufenuron & 15.00 \\
V10 & Flubendiamide & 72.00 \\
V12 & Chlorantraniliprole & 25.00 \\
R1 & Methomyl & 126.00 \\
R1 & Lufenuron & 15.00 \\
R2 & Chlorantraniliprole & 25.00 \\
\hline
\end{tabular}

sprayer with a nozzle that allowed a solid cone spray at a flow rate of $200 \mathrm{~L} \mathrm{ha}^{-1}$ at a speed of $3.6 \mathrm{~km} \mathrm{~h}^{-1}$. The insecticide spraying was carried out in a row by row fashion in an attempt to cover the entire plant during the vegetative stages, directing the spray towards the corn ears only during the reproductive stages.

To assess the leaf injury caused by Spodoptera frugiperda larvae we selected 20 plants in the second outermost row in every replicate, and at stages V4, V6, V8, V10 we randomly chose one of these plants to be visually evaluated (the same plant was never assessed twice). During this evaluation the leaf injuries received grades according to the Davis scale (Davis et al., 1992), where leaves with no injury were assigned grade zero and those with the largest/most severe injuries were assigned grade 9 (a gradient of intermediary grades were used between zero and 9). In addition, at stage R3 we surveyed for lepidopteran larvae attacking the corn ears and assessed the injury inflicted upon both kernels and corn cobs. This evaluation was carried out by choosing at random ten corn ears from different plants located in the two second-outermost rows of each replicate. The larvae found were collected and identified to the genus level, and thereafter the surface area injury to the kernels and corn cob was estimated using a clear plastic sheet with grids measuring $0.5 \mathrm{~cm}^{2}$.

At the end of the experiments the corn ears from all plants in the two inner-most rows of each replicate were manually harvested, and the following parameters measured: (i) corn ear weight without the husk, (ii) length and diameter of corn ears without the husk, and (iii) kernel yield by subtracting the cobs' weight from the grains' weight.

Environmental conditions (temperature and precipitation) were monitored regularly by a field weather station (Davis Vantage Pro2 model) located $500 \mathrm{~m}$ away from the experimental area.

\section{Statistical analyses}

Differences between treatments in terms of leaf injury (Davis grading) were tested by conducting repeated measures ANOVA (PROC MIXED) for each experiment separately. Repeated measures ANOVA was chosen because the data were collected repeatedly from the same plots over time. Covariance structures for the mixed model repeated measures were constructed, and Bayesian Information Criterion (BIC) were used to assess that the ARH (1) (First-order Autoregressive) and TOEPH (1) (Heterogeneous Toeplitz) covariance structure provided the best fit for the data from experiments 1 and 2, respectively.

Differences between treatments regarding the parameters (i) weight of corn ears, (ii) length and diameter of corn ears, and (iii) kernel yield were tested by carrying out separate multivariate analyses (MANOVA, PROC GLM) for each experiment. Whenever we found a significant difference between treatments a pairwise comparison between means was made using LSMEANS. Prior to 
running a MANOVA the assumption of normality was assessed by evaluating the variance equality (plotting residuals vs. estimates) and conducting a Levene's test.

Similarly, multivariate analyses (MANOVA) were also conducted to test for differences between treatments regarding larvae injury on kernels and corncobs, as well as the number of lepidopteran larvae ( $S$. frugiperda and Helicoverpa sp.) (pooling the data from both experiments) in the different treatments. All statistical analyses were carried out using the SAS program (Statistical Analysis Software, version 9.2).

\section{Results}

For experiment 1, there was a significant effect of the corn and insecticide factors, their interaction with each other, and a three way interaction with time that affected leaf injury grades (Table 2). By contrast, in experiment 2 only the corn factor and its combined inter-

Table 2 - Statistical analyses results for the main effects and its interactions.

\begin{tabular}{|c|c|c|c|}
\hline \multicolumn{4}{|c|}{ Experiment 1} \\
\hline Responses & Effect & $\mathrm{F}$ & $p$ \\
\hline \multirow{5}{*}{$\begin{array}{l}\text { leaf injury }{ }^{1} \\
\text { (Davis grading) }\end{array}$} & block & 2.06 & 0.1208 \\
\hline & corn & 64.36 & $<0.0001$ \\
\hline & Insecticide & 20.10 & 0.0002 \\
\hline & corn*insecticide & 6.74 & 0.0176 \\
\hline & corn ${ }^{*}$ insecticide ${ }^{\star}$ time & 9.11 & $<0.0001$ \\
\hline \multirow{3}{*}{ Injury on kernels and $\mathrm{cob}^{2}$} & corn & 64.78 & $<0.0001$ \\
\hline & insecticide & 0.69 & 0.5158 \\
\hline & corn*insecticide & 0.27 & 0.7631 \\
\hline \multirow{3}{*}{$\begin{array}{l}\text { corn ear }{ }^{2} \text { : weight without the } \\
\text { husk, diameter and length, } \\
\text { kernel yield }\end{array}$} & corn & 4.86 & 0.0068 \\
\hline & insecticide & 0.27 & 0.9213 \\
\hline & corn*insecticide & 2.25 & 0.0990 \\
\hline \multicolumn{4}{|c|}{ Experiment 2} \\
\hline Responses & Effect & $\mathrm{F}$ & $p$ \\
\hline \multirow{5}{*}{$\begin{array}{l}\text { leaf injury }{ }^{1} \\
\text { (Davis grading) }\end{array}$} & block & 2.30 & 0.0829 \\
\hline & corn & 18.01 & $<0.0001$ \\
\hline & Insecticide & 1.75 & 0.1974 \\
\hline & corn*insecticide & 0.13 & 0.8779 \\
\hline & corn ${ }^{*}$ insecticide ${ }^{\star}$ time & 15.20 & $<0.0001$ \\
\hline \multirow{3}{*}{ Injury on kernels and cob $^{2}$} & corn & 20.84 & 0.0001 \\
\hline & insecticide & 2.57 & 0.1027 \\
\hline & corn*insecticide & 0.84 & 0.4461 \\
\hline \multirow{3}{*}{$\begin{array}{l}\text { corn ear }{ }^{2} \text { : weight without the } \\
\text { husk, diameter and length, } \\
\text { kernel yield }\end{array}$} & corn & 10.01 & 0.0001 \\
\hline & insecticide & 1.92 & 0.1475 \\
\hline & corn*insecticide & 3.88 & 0.0170 \\
\hline \multicolumn{4}{|c|}{ Experiment $1+$ Experiment 2} \\
\hline Responses & Effect & $\mathrm{F}$ & $p$ \\
\hline \multirow{6}{*}{$\begin{array}{l}\text { number of lepidopteran } \\
\text { larvae }^{2}\end{array}$} & time & 11.32 & 0.0001 \\
\hline & corn & 64.78 & $<0.0001$ \\
\hline & insecticide & 0.90 & 0.4140 \\
\hline & time ${ }^{*}$ corn & 7.02 & 0.0024 \\
\hline & time*insecticide & 1.45 & 0.2469 \\
\hline & corn*insecticide & 1.17 & 0.3208 \\
\hline
\end{tabular}

${ }^{1}$ Repeated measures ANOVA (PROC MIXED); ${ }^{2}$ Multivariate ANOVA (MANOVA). action with the insecticide and time factors had a significant effect on differences in leaf injury (Table 2). During the first experiment we detected more severe leaf injury in the control treatment (conventional w/o insecticide) (Figure 1). By comparison, the least severe leaf injury was observed in treatments with Bt sweet corn, regardless of the application of insecticide (Figure 1). Nonetheless, the application of insecticide was able to significantly reduce the leaf injury caused by $S$. frugiperda when compared with the control treatment (Figure 1). In general, the leaf injury caused by $S$. frugiperda in all treatments during the second experiment was relatively less severe than what had been observed in the first experiment (Figure 1). Nevertheless, as in the first experiment the Bt corn treatments still showed the least severe leaf injury during the second experiment, regardless of the application of insecticide (Figure 1). The application of insecticides also reduced leaf injury in conventional corn in the second experiment, especially on the last two evaluation dates (Figure 1).

There was a significant effect of the factor corn on the differences in kernel and cob injury caused by lepidopterans (most likely Helicoverpa spp.) in both experiments (Table 2). However, there was no significant
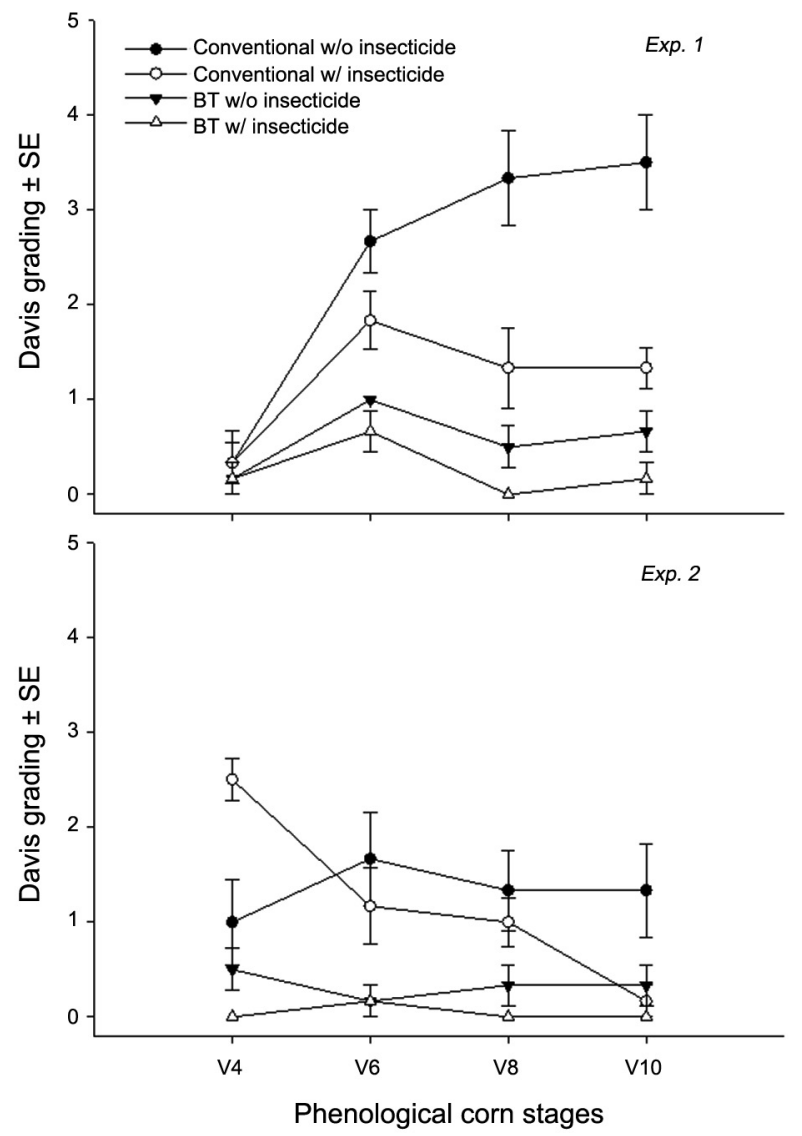

Figure $1-$ Mean \pm SE of defoliation by $S$. frugiperda using Davis rating scale in both experiments at the phenological stages $\mathrm{V} 4$, V6, V8 and V10. 
effect of the insecticide factor alone or its interaction with the corn factor (Table 2). The injury inflicted on the kernels and cobs by lepidopteran larvae was significantly less severe on the treatments with Bt sweet corn in experiment 1 , irrespective of the application of insecticide (Figure 2). This same pattern was observed for experiment 2. However, there was no difference in kernel injury between Bt sweet corn and conventional corn sprayed with insecticides (Figure 2).

There was also a significant effect of the factors corn, time and their interaction on the number of lepidopteran larvae found attacking sweet corn in both experiments (Table 2). The species of Lepidoptera larvae encountered were Helicoverpa spp. and S. frugiperda (Figure 3), the former being the most common. These lepidopteran larvae were able to cause significant injury to the corn ears, especially in the control treatment (conventional w/o insecticide) (Figure 2). Despite the relative low number of larvae sampled during both experiments, it was still possible to detect a significantly lower number of larvae (Helicoverpa spp. and $S$. frugiperda) on the Bt sweet corn treatments during both experiments, regardless of the application of insecticide (Figure 3).
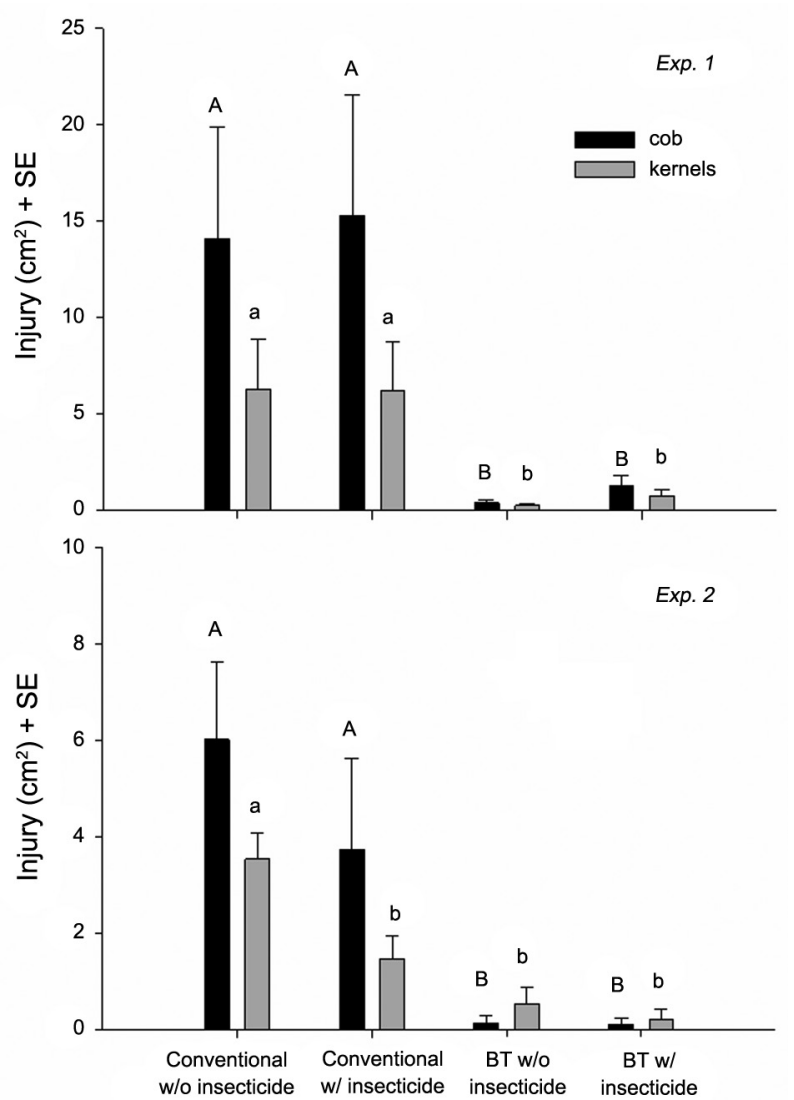

Figure 2 - Injury caused by lepidopteran larvae on cobs and kernels in both experiments. Bars followed by different letters (separated by cob and kernels) do not differ statistically at $p>$ 0.05 (LSMEANS, MANOVA).

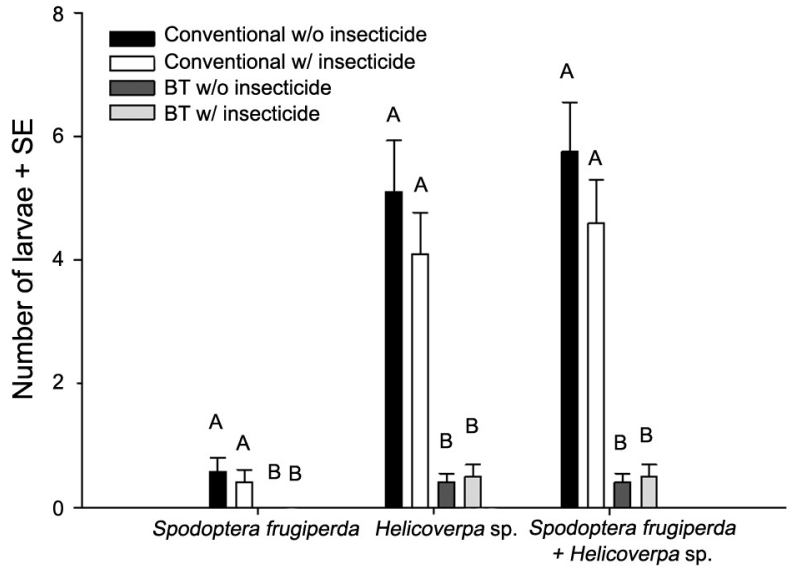

Figure 3-Species and number of lepidopteran larvae found attacking the corn ears (10 corn ears/replicate) at the phonological stage R3. Bars followed by different letters do not differ statistically at $p$ $>0.05$ (LSMEANS, MANOVA).

The parameters' corn ear weight, diameter and length, as well as the kernel yield were significantly affected by the factor corn in both experiments (Table 2), and a significant interaction between the factors corn and insecticide was detected during experiment 2 (Table 2 ). The corn ear weight and length were significantly higher for the Bt corn in both experiments, regardless of the application of insecticide, followed by conventional corn sprayed with insecticide (Table 3). Nonetheless, values for corn ear weight and length in experiment 2 were significantly higher on Bt plants and conventional plants treated with insecticide (Table 3). There was a tendency to a wider diameter in corn ears from treatments with Bt sweet corn and conventional corn sprayed with insecticide in the first experiment, and no significant difference in the second experiment (Table 3). The treatments with Bt sweet corn and conventional sprayed corn also allowed for the highest kernel yield in both experiments (Table 3).

\section{Discussion}

According to the leaf injury analysis (Davis et al., 1992) the lowest $S$. frugiperda defoliation grades were given to the $\mathrm{Bt}$ treatments in both experiments (Figure 1). Conventional corn treated with insecticide also received low grades in experiment 2 when nearing the phonological stage V10. In general, the better performance of the Bt technology is likely due to the fact that $S$. frugiperda larvae hatching on Bt plants start ingesting the protoxin very early, thus allowing for a swifter 'poisoning' of the susceptible pest (Gill et al., 1992). By contrast, it is expected that $S$. frugiperda larvae hatching on conventional plants will have their first contact with insecticide molecules influenced by the timing of the spraying and spray coverage. Nevertheless, the results suggest that Bt sweet corn alone 
Table 3 - Measurements of corn ears weight (EW), diameter (ED), length (EL), and kernel yield, in response to four experimental treatments.

\begin{tabular}{|c|c|c|c|c|c|c|}
\hline Experiment & Corn & Insecticide & $\mathrm{EW}^{*}$ & ED & EL & Kernel Yield ${ }^{\dagger}$ \\
\hline \multirow{5}{*}{1} & & & $\mathrm{~g}$ & \multicolumn{2}{|c|}{$\mathrm{cm}$} & $\mathrm{g}$ \\
\hline & Bt & With & $11170.00 \pm 571.34 \mathrm{~A}$ & $5.44 \pm 0.08 \mathrm{AB}$ & $21.27 \pm 0.50 \mathrm{~A}$ & $6588.3 \pm 383.47 \mathrm{~A}$ \\
\hline & $\mathrm{Bt}$ & Without & $11551.70 \pm 351.50 \mathrm{~A}$ & $5.62 \pm 0.04 \mathrm{~A}$ & $21.72 \pm 0.44 \mathrm{~A}$ & $6980.0 \pm 233.56 \mathrm{~A}$ \\
\hline & Conv. & With & $9720.00 \pm 427.44 A B$ & $5.45 \pm 0.09 \mathrm{AB}$ & $20.11 \pm 0.47 \mathrm{AB}$ & $5865.0 \pm 316.31 \mathrm{~A}$ \\
\hline & Conv. & Without & $8975.00 \pm 555.83 B$ & $5.21 \pm 0.12 \mathrm{~B}$ & $18.91 \pm 0.38 \mathrm{~B}$ & $5331.6 \pm 320.35 B$ \\
\hline \multirow{4}{*}{2} & $\mathrm{Bt}$ & With & $11051.70 \pm 201.35 \mathrm{~A}$ & $5.56 \pm 0.05 \mathrm{~A}$ & $17.11 \pm 0.50 \mathrm{~A}$ & $7255.0 \pm 163.79 \mathrm{~A}$ \\
\hline & $\mathrm{Bt}$ & Without & $11070.00 \pm 269.16 \mathrm{~A}$ & $5.63 \pm 0.05 \mathrm{~A}$ & $18.36 \pm 0.38 \mathrm{~A}$ & $7253.3 \pm 211.39 \mathrm{~A}$ \\
\hline & Conv. & With & $10851.70 \pm 179.75 \mathrm{~A}$ & $5.47 \pm 0.06 \mathrm{~A}$ & $16.15 \pm 0.28 \mathrm{AB}$ & $6987.5 \pm 148.36 \mathrm{~A}$ \\
\hline & Conv. & Without & $9365.00 \pm 286.18 \mathrm{~B}$ & $5.47 \pm 0.02 \mathrm{~A}$ & $14.98 \pm 0.26 B$ & $5990.0 \pm 180.89 \mathrm{~B}$ \\
\hline
\end{tabular}

Means followed by the same letters within columns (by experiment) do not differ statistically at $p>0.05$ (LSMEANS, MANOVA); ${ }^{*}$ Corn ear weight of all ears harvested from the two central rows in each replicate; 'Kernel yield from all corn ears harvested from the two central rows in each replicate.

can limit the $S$. frugiperda leaf injury to below its economic injury level (20\% of Davis grades $\geq 3$ ) (Michelotto et al., 2011) up to the V10 phenological stage. The high level of effectiveness of Bt sweet corn was probably due to the high Bt-toxin susceptibility of the lepidopterans in the field.

The application of insecticide on conventional corn significantly reduced the leaf injury caused by $S$. frugiperda compared to the control (conventional corn without insecticide). However, this reduction in leaf injury was relatively delayed compared to the Bt treatments. In any case, one could expect that the integration of Bt technology into the application of insecticide is compatible and would allow for reduced selection pressure to select either Bt- or insecticide-resistant individuals (Romeis et al., 2008). Additionally, the factor time also appeared to influence the Davis grades (Figure 2), which were relatively lower in the second experiment. This was most likely due to the fact that $S$. frugiperda attack corn leaves mainly between the V6 and V10 stages (Cruz and Turpin, 1982), which coincided with a time of higher precipitation values in the second experiment, and this is known to negatively affect the population of this insect pest (Varella et al., 2015). It is also noteworthy that these data do not enable us to discuss the size of the $S$. frugiperda population since the grades are based on the level of defoliation only and not on the number of larvae present.

The injury caused by Lepidoptera larvae on corncob and kernels was significantly less severe on Bt plants compared to conventional ones in the first experiment, regardless of the use of insecticide. However, the application of insecticide on conventional corn plants appeared to protect the kernels equally as well as the Bt plants during the second experiment (Figure 2). The satisfactory protection provided by the Bt technology to corncob and kernels is probably because a substantial amount of the toxin is expressed in the green tissues such as the husk (Yun-Jun and Guo-Ying, 2003), on which Lepidoptera larvae feed before reaching the kernels or cob. Similar to the defoliation caused by $S$. frugiperda the cob and kernel injury was also less severe in the second experiment, which may also be a result of the higher precipitation values observed in the second experiment as discussed previously.

Spodoptera frugiperda and Helicoverpa sp. were the only Lepidoptera larvae that we encountered attacking corn ears in the field. We were not able to distinguish between Helicoverpa zea and Helicoverpa armigera larvae, where the latter is a new invasive species in Brazil (Tay et al., 2013). Despite the low number of Lepidoptera larvae sampled, a significantly smaller number of larvae were found on corn ears of the Bt plants (Figure 3). This is in accordance with previous results and discussion about the reduced corncob and kernel injury measured on these Bt treatments. We found fewer $S$. frugiperda larvae on corn ears compared to Helicoverpa sp., which is expected since $S$. frugiperda prefer to feed on the leaves (Cruz and Turpin, 1982).

Overall the results in terms of the parameters corn ear weight, diameter, length and kernel yield were better in the Bt treatments and conventional corn sprayed with insecticide compared to the control (Table 3). No additive or synergistic effects stemming from the combination of Bt technology and insecticide were observed influencing the aforementioned parameters.

In summary, the results of these two field experiments show the potential for the use of Bt technology to control lepidopteran pests attacking sweet corn in Brazil. Additionally, the results suggest that Bt sweet corn is not dependent on the application of insecticide to supplement pest control, which could translate to reduced chemical use for lepidopterans. However, in the long term the integration of Bt technology and chemical control is important for reducing selection pressure posed by Bt corn on lepidopterans, and for controling eventual Bt-resistant individuals that might be in the population. Lastly, because various lepidopteran pests have already been exposed to conventional Bt corn it is of paramount importance to deploy novel protoxins in sweet corn that will help prevent resistance to develop.

\section{Acknowledgments}

We thank the FAPEG agency (Fundação de Amparo à Pesquisa do Estado de Goiás) for providing a gradu- 
ate research assistantship. Special thanks to Nadson Pontes for insightful comments on the manuscript. Many thanks also to Wilmar Morjan and Fabricio Francischini for providing invaluable suggestions regarding the conducting of our experiments. This work was supported by FAPEMIG - Fundação de Amparo à Pesquisa do Estado de Minas Gerais (Grant FORTIS-TCT-10254/2014).

\section{Authors' Contributions}

Conceptualization: Schneider, A.M., Gontijo, L.M., Costa, L.L. Data analysis: Gontijo, L.M. Data acquisition: Schneider, A.M. Design of methodology: Schneider, A.M., Gontijo, L.M. Writing and editing: Schneider, A.M., Gontijo, L.M., Costa, L.L.

\section{References}

Comissão Técnica Nacional de Biossegurança [CTNBio]. 2009. Tecnical Assessment 2052/2009 = Parecer técnico. Available at: http://ctnbio.mcti.gov.br/liberacao-comercial/-/document_ library_display/SqhWdohU4BvU/view/1475150\#/liberacaocomercial/consultar-processo [Accessed Aug 19, 2016] (in Portuguese).

Cruz, I.; Turpin, F.T. 1982. Effect of Spodoptera Frugiperda on different growth stages of corn. Pesquisa Agropecuária Brasileira 17: 355-359 (in Portuguese, with abstract in English).

Davis, F.M.; Ng, S.S.; Williams, W.P. 1992. Visual rating scales for screening whorl-stage corn for resistance to fall armyworm. Mississippi Agriculture and Forestry Experimental Station. Technical Bulletin 186: 9.

Drury, S.M.; Reynolds, T.L.; Ridley, W.P.; Bogdanova, N.; Riordan, S.; Nemeth, M.A.; Sorbet, R.; Trujillo, W.A.; Breeze, M.L. 2008. Composition of forage and grain from secondgeneration insect-protected corn MON 89034 is equivalent to that of conventional corn (Zea mays L.). Journal of Agricultural and Food Chemistry 56: 4623-4630.

Gill, S.S.; Cowles, E.A.; Pietrantonio, P.V. 1992. The mode of action of Bacillus thuringiensis endotoxins. Annual Review of Entomology 37: 615-634.

James, C. 2013. Global Status of Commercialized Biotech/GM Crops: ISAAA Brief. 2013, 46. ISAAA: Ithaca, NY, USA.

Meissle, M.; Romeis, J.; Bigler, F. 2011. Bt maize and integrated pest management: a European perspective. Pest Management Science 67: 1049-1058.

Michelotto, M.D.; Finoto, E.L.; Martins, A.L.M.; Duarte, A.P. 2011. Interaction between transgenics and insecticides in the control of key pests on off-season maize hybrids. Arquivos do Instituto Biológico 78: 71-79 (in Portuguese, with abstract in English).
Musser, F.R.; Shelton, A.M. 2003. Bt sweet corn and selective insecticides: impacts on pests and predators. Journal of Economic Entomology 96: 71-80.

Phipps, R.H.; Park, J.R. 2002. Environmental benefits of genetically modified crops: global and European perspectives on their ability to reduce pesticide use. Journal of Animal and Feed Science 11: 1-18.

Romeis, J.; Meissle, M.; Bigler, F. 2006. Transgenic crops expressing Bacillus thuringiensis toxins and biological control. Nature Biotechnology 24: 63-71.

Romeis, J.; Shelton, A.M.; Kennedy, G.G. 2008. Integration of Insect-Resistant Genetically Modified Crops within IPM Programs. Springer, New York, NY, USA.

Shelton, A.M.; Zhao, J.Z.; Roush, R.T. 2002. Economic, ecological, food safety, and social consequences of the deployment of Bt transgenic plants. Annual Review of Entomology 47: 845-881.

Shelton, A.M.; Olmstead, D.L.; Burkness, E.C.; Hutchinson, W.D.; Dively, G.; Welty, C.; Sparks, A.N. 2013. Multi-state trials of Bt sweet corn varieties for control of the corn earworm (Lepidoptera: Noctuidae). Journal of Economic Entomology 106: 2151-2159.

Siebert, M.W.; Nolting, S.P.; Hendrix, W.; Dhavala, S.; Craig, C.; Leonard, B.R.; Stewart, S.D.; All, J.; Musser, F.R.; Buntin, G.D.; Samuael, L. 2012. Evaluation of corn hybrids expressing Cry1F, Cry1A.105, Cry2Ab2, Cry34Ab1/Cry35Ab1, and Cry3Bb1 against southern United States insect pests. Journal of Economic Entomology 105: 1825-1834.

Tay, W.T.; Soria, M.F.; Walsh, T.; Thomazoni, D.; Silvie, P.; Behere, G.T.; Anderson, C.; Downes, S. 2013. A brave new world for an old world pest: Helicoverpa armigera (Lepidoptera: Noctuidae) in Brazil. Plos One 8: e80134. doi.org/10.1371/ journal.pone.0080134

Valicente, F.H. 2015. Pest management $=$ Manejo de pragas. $\mathrm{p}$. 273-293. In: Borém A.; Galvão; J.C.C.; Pimentel, M.A., eds. Corn: From the sowing to the harvesting $=$ Milho: do plantio à colheita. Editora UFV, Viçosa, MG, Brazil (in Portuguese).

Varella, A.C.; Menezes-Netto, A.C.; Alonso, J.D.S.; Caixeta, D.F.; Peterson, R.K.D.; Fernandes, O.A. 2015. Mortality dynamics of Spodoptera frugiperda (Lepidoptera: Noctuidae) immatures in maize. Plos One 10: e0130437. DOI:10.1371/journal. pone. 0130437

Yun-Jun, L.; Guo-Ying, W. 2003. The inheritance and expression of Cry $1 \mathrm{~A}$ gene in transgenic maize. Acta Botanica Sinica 45: 253-256. 